\title{
Motivation Factors for Elementary School Students
}

\author{
Luka Pongračić*, Dea Lazić Hasanagić and Ljiljana Tadić Komadina \\ Juraj Dobrila University of Pula, Croatia
}

\section{ARTICLE INFO}

Keywords:

Anxiety

Extrinsic motivation

Intrinsic motivation

Level of motivation

\begin{abstract}
It is not hard to recognise motivated student. He is interested, curious, active, enthusiastic and does not give up when encounters difficulties, but thinks for further education. Motivation during schooling is highly related to a student's later academic achievement and it is therefore very important to encourage it. This paper discusses the motivation factors and affective component for elementary school students. The empirical research has been carried out through a questionnaire based on the instrument Motivated Strategies for Learning Questionnaire (MSLQ) designed and adjusted for researching intrinsic goal orientation, extrinsic goal orientation and anxiety of Croatian elementary school students (1st -4 th grade). The sample of this research consisted of 311 primary school students from rural $(\mathrm{N}=103)$ and urban $(\mathrm{N}=208)$ primary schools. The research was conducted during 2019 in several Croatian counties. The aim of the paper is to determine levels of three motivation factors: intrinsic goal orientation, extrinsic goal orientation and anxiety as an important predictor of future academic success. Secondary goal is to determine differences according to gender, age and the living environment of students. The results had shown that the overall level of motivation of the participants is high from which it is evident that students are highly motivated to work, especially female students. The results also show high level of intrinsic goal orientation, higher level of extrinsic goal orientation and test anxiety comparing to Duncan et. al. (2015) results.
\end{abstract}

\section{Introduction}

It is complex to discuss about teaching because it is most often identified with school lessons. However, schooling is a more complex activity then teaching itself (Vujčić, 2013). Teaching is a dynamic process between students and teachers with the aim of educating and preparing students for the future (Borić, 2017). Teaching as a process includes planning, implementation and evaluation (Zhang, et al., 2011). Each of this part is a complex task. Halusek \& Špoljarić (2014) differ formal and real lesson planning. Formal planning stands for filling the required administration and real planning stands for choosing the methods, teaching content sources and adapting them to the students. Furthermore, the process of implementation begins and ends in the classroom during the planned activities and lesson realisation. Teaching process ends with the evaluation which is an ,important activity for both student and teacher (Matijević, 2005, 279).

\footnotetext{
*Corresponding author E-mail address: lukapongracic2@gmail.com

Cite this article as:

Pongračić, L., Lazić Hasanagić, D. \& Tadić Komadina, L. (2021). Motivation Factors for Elementary School Students. European Journal of Teaching and Education, 3(1):1-10. https://doi.org/10.33422/ejte.v3i1.646

(C) The Author(s). 2021 Open Access. This article is distributed under the terms of the Creative Commons Attribution 4.0 International License, which permits unrestricted use, distribution, and redistribution in any medium, provided that the original author(s) and source are credited.
} 
Learning is a psychological process. Without learning there is no education. Each form of education presupposes a certain way of student reaction and each of these reactions is nothing but learning (Vujčić, 2013). Yilmaz (2008; according to Borić \& Škugor, 2014) defines learning as an active process, an adaptable and changeable activity, placed in the context in which it occurs. Tot (2010; according to Borić, 2017) considers that modern teaching encourages self - learning. Specific student - teacher relationships are very important because they are focused on motivation and student independence. The ultimate goal of self regulated learning is development of student's personality, individuality and originality.

Motivation has been discussed about since the age of the famous Greek philosophers as Plato. Since that time many authors has wrangled the term of motivation (Stellar \& Stellar, 1985) but in Croatian pedagogical dictionary this term didn't occur until the late 1960s (Jakšić, 2003). According to Vallerand \& O'Connor (1989) motivation began to study because of three reasons: 1. it helped us to understand the factors that regulate behaviour, 2. it was necessary for more complete picture of the psychological process, 3 . for better understanding of the factors that influence mental and physical health. Reeve (2009; according to Borić, 2017) denoted motivation as an influence that causes, directs and sustains the desired behaviour of people. Phillips and Lindsay (2006; in Altun \& Yazici, 2014) claim that motivation is a key factor of some great success and performance. Motivation appears when there is a desire to learn and it is deeply related to school success. Horga (1993; according to Bogdan \& Babačić, 2015) says that motivation is a set of impulses of individuals for a certain act which needs to be activated in order to achieve a determinate goal. It can be concluded that motivation is the process of initiating, directing, determining the strength and duration of activities by which we want to achieve the goal. No activity arises by itself, but each is caused by some eternal motivation or external stimulus which can be positive or negative.

\section{Motivation Factors and Affective Component for Elementary School Students}

Motivation for learning are internal and external factors (motives) that led the individual to learn active, which determined the direction, intensity and duration of learning or any other activity. The goals that we want to achieve with these activities are called motivation goals. It is not hard to recognise motivated student. He is interested, curious, active, enthusiastic and does not give up when encounters difficulties, but thinks for further education. He is satisfied with the lessons and the amount of his knowledge. However, despite the motivation, in order to achieve a certain goal, it is necessary for him to make an effort (Jakšić, 2003). Croatian psychologist Grgin (1982; according to Jakšić, 2003) has conducted research about the types of students' motivation. The research included $7^{\text {th }}$ grade elementary school students and $2^{\text {nd }}$ and $4^{\text {th }}$ secondary school students. The researcher confirmed positive motivation domination over the negative one. He also found out that in $7^{\text {th }}$ grade elementary school and $2^{\text {nd }}$ secondary school dominates external motivation and in $4^{\text {th }}$ secondary school predominates internal motivation. We can conclude that motives change with nurturing intrinsic motivation through schooling and with maturing. Motivation during schooling is highly related to a student's later academic achievement (Wentzel, 1998; Broussard \& Garrison, 2004; Amrai et al., 2011) and it is therefore very important to encourage it.

There are two main forms of stimulating school students for learning: intrinsic motivation and extrinsic motivation.

\subsection{Intrinsic Motivation}

Intrinsic motivation comes from latin word inter which means inside. Horga (1993; according to Bogdan \& Babačić, 2015) defines intrinsic motivation as a set of internal factors that act on an individual in a way of internal support for achieving a goal. Internal motives include: curiosity, the need for competence and the need for self - actualisation (Jakšić, 2003). This 
type of motivation creates an individual's personal desire to take actions, not necessary to accomplish external awards. Individual is satisfied by performing the activity itself because loves it or is interested in it. Internal motivation is very strong and long lasting so it can influence on an individual for a lifetime. Student perceives such contents as cognitively valuable and practically useful so he adopts and retains it faster and he perceives them easy and pleasant. Vujčić (2013) warns that sometimes the importance of intrinsic motivation is unjustifiably exaggerated. He also claims that intrinsic motivation is not always impossible without extrinsic goals.

\subsection{Extrinsic Motivation}

Extrinsic motivation is stimulated by some attractive external motive (Borić, 2017). The term comes from latin word extra which means outside and it is triggered by desire to earn additional bonuses such as trophies, financial resources, evaluation, competition etc. These material rewards will encourage individuals to work harder and harder to achieve their goals (Horga 1993; according to Bogdan \& Babačić, 2015). Beside positive stimuluses there are also the negative ones such as punishment. They can also encourage individuals to succeed. External motivation has an influence on internal motivation. If the external motivation is good it will increase the internal motivation, and if external motivation is bad it will threaten internal one. According to Hammerl et al. (2009) there are three external motivation problems. All three of them refer to external rewards. The first problem is short time and possibly ineffective changes produced by external rewards. The second one is reducing students' interest in something by rewarding them and the third one applies to reducing students' qualities by controlling them.

Sometimes negative motives can result in positive outcomes (for example rebuke or bad grade sometimes can make positive effect on student behaviour and learning). However, teacher should not exaggerate in negative affective components because it can lead to negative outcomes, such as anxiety. One of the most common sources of anxiety in schools are exams.

\subsection{Anxiety}

According to Kaplan (2004; according to Sakač et al., 2017) psychologists define anxiety as a condition accompanied by an increased degree of psychological irritability. It is an unpleasant emotional state full of fears and concerns. Children anxiety is equated with intense fear or disturbance. March (2000; according to Sakač et al., 2017) also mentions physical symptoms, such as stuttering or sweating, which can negatively affect at child's mental condition. In some case long term anxiety leeds to quiting the school (Wenar 2003; according to Sakač et al., 2017). Exam anxiety is so distracting for some students that they have to seek professional help (Spielberger \& Vagg, 1955; according to Juretić, 2008). Autors Tomljenović \& Nikčević - Milković (2005) have studied the role and significance of test anxiety in Croatian schools. The results gave a negative association between exam anxiety and self - esteem, as well as school achievement.

\section{Methodology}

\subsection{Aim of Research}

The main goal of this research is to determine the level of motivation of primary school students and as well to determine levels of three motivation factors: intrinsic goal orientation, extrinsic goal orientation and anxiety.

Secondary goal is to determine differences according to gender, age and the living environment of students. 


\subsection{Participants}

The sample of this research consisted of 311 primary school students from rural $(\mathrm{N}=103)$ and urban $(\mathrm{N}=208)$ primary schools. 149 male and 162 female students participated in the study. In addition to gender, participants were divided according to age into younger students (6, 7 and 8 years) with 132 students and older students (9, 10 and 11 years) with 179 students.

\subsection{Instrument}

Duncan et al. (2015) made a list of motivation scales designed to measure students' motivation which includes value, expectancy and affective components. Each component is divided into factors. The value component includes intrinsic and extrinsic goal orientation as well as task value. Furthermore, expectancy component contains control beliefs and self efficacy for learning and performance. Test anxiety is an affective component. In our research we used three of listed factors: intrinsic, extrinsic goal orientation and test anxiety. Data were collected by the Questionnaire Motivated Strategies for Learning Questionnaire ${ }^{1}$ (MSLQ) (Pintrich et al., 1991) with translation to Croatian language. Questionnaire reliability test on all 25 particles expressed with Cronbach alpha coefficient is 0,726 which is within an acceptable framework (Duncan et al., 2015, 7). Manual (Duncan et al., 2015) did not provided norms and this paper uses results shown in Manual as referent scale points. Original MSLQ has Likert's scale from 1 to 7 and for this research is adapted to Likert's scale from 1 to 5 for younger students. For this research is chosen 25 particles from complete questionnaire of 81 to test only researched components of motivation strategies.

\subsection{Procedure}

The research was conducted during 2019 in several Croatian counties. The questionnaire was conducted anonymously and transversely with the written consent of the students 'parents, the students' consent and the permission of the school principal. Data were processed using SPSS Statistics v21 for Windows. All students' self-assessment questions are on the Likert's scale from 1 to 5 .

\subsection{Results and Discussion}

The Motivated Strategies for Learning Questionnaire (MSLQ) (Pintrich et. al., 1991) determined the overall level of student motivation, which is expressed by the sum of the results of all responses of each participant. The overall level of motivation of the participants is high $(\mathrm{N}=311$, mean $=97.87$, median $=99, \mathrm{SD}=11.15$, kurt. $=0.52, \min =67, \max =123$, range $=56$ ), which shows that students are highly motivated to study (Figure 1).

There are also larger deviations from the expected values where we have students with very low levels of motivation with minimum value count of 67 and $28.6 \%$ participants in lower 25 percentiles with level of motivation under count of 85 . There are also those with extremely high levels of motivation with maximum value count of 123 and 34\% participants in upper 75 percentiles with levels of motivation higher than 106 (Figure 2).

\footnotetext{
${ }^{1}$ Only part of the questionnaire was used in the research. Out of a total of 81 questions, 25 questions corresponding to the factors researched in the paper were used.
} 


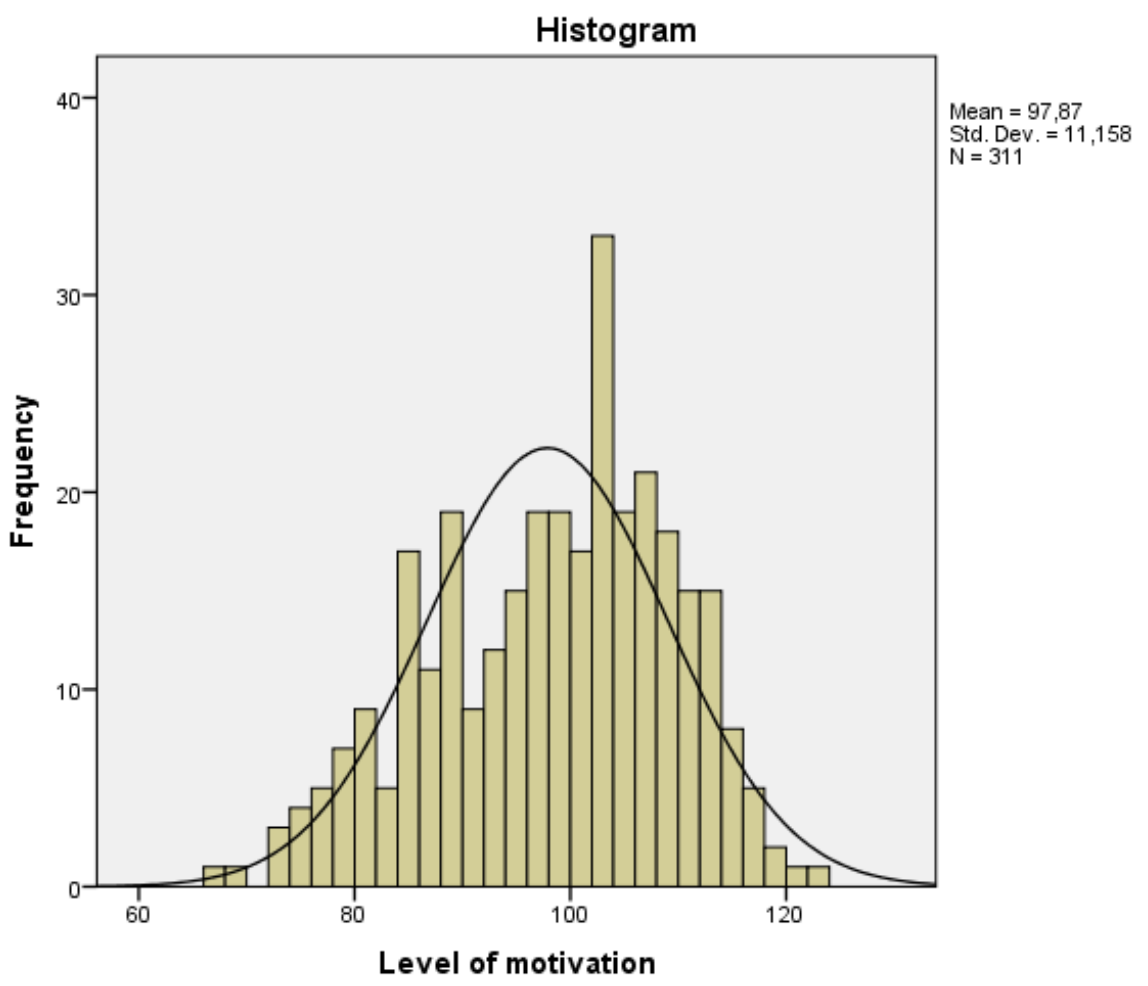

Figure 1. Level of motivation

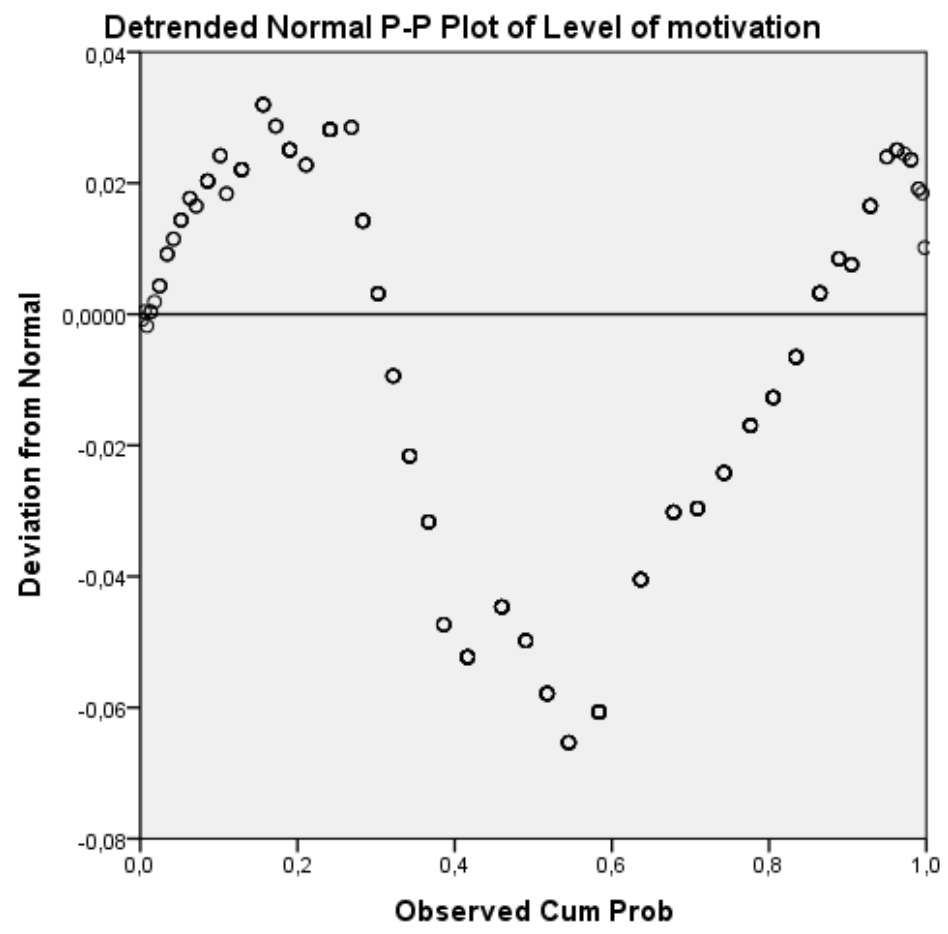

Figure 2. Deviation from normal level of motivation

The results show a statistically significantly higher motivation in girls $(\mathrm{t}=2.17, \Delta$ mean $=$ $2.74, \mathrm{p}<0.05)$. Given the age of the participants, the results are almost the same $(\Delta$ mean $=$ 0.01 ), from which it is concluded that the level of motivation does not increase with the years of schooling, but maintains almost the same level. Observed towards the living environment there is also no statistically significant difference $(\mathrm{t}=0.98, \Delta$ mean $=1.32, \mathrm{p}>0.05)$. Similar 
research (Baharudin \& Zulkefly, 2009) shows that girls show significantly better success in school than boys, which coincides with this research where a higher level of motivation is visible in girls, which is certainly directly related to greater success. Although research (Dubow et al., 1991) shows a decline in success as a trend that develops over the years, this has not been shown here.

\subsubsection{Intrinsic Goal Orientation}

Intrinsic motivation was examined in four questions and the results were as follows: mean = 3.89 , median $=4, \mathrm{SD}=0.79$, kurt. $=0.24, \min =1.25, \max =5$ (Figure 3). Compared with the results of Duncan et al. (2015) which amounted to mean $=3.59^{2}$ the results of the conducted questionnaire show higher values of intrinsic motivation.

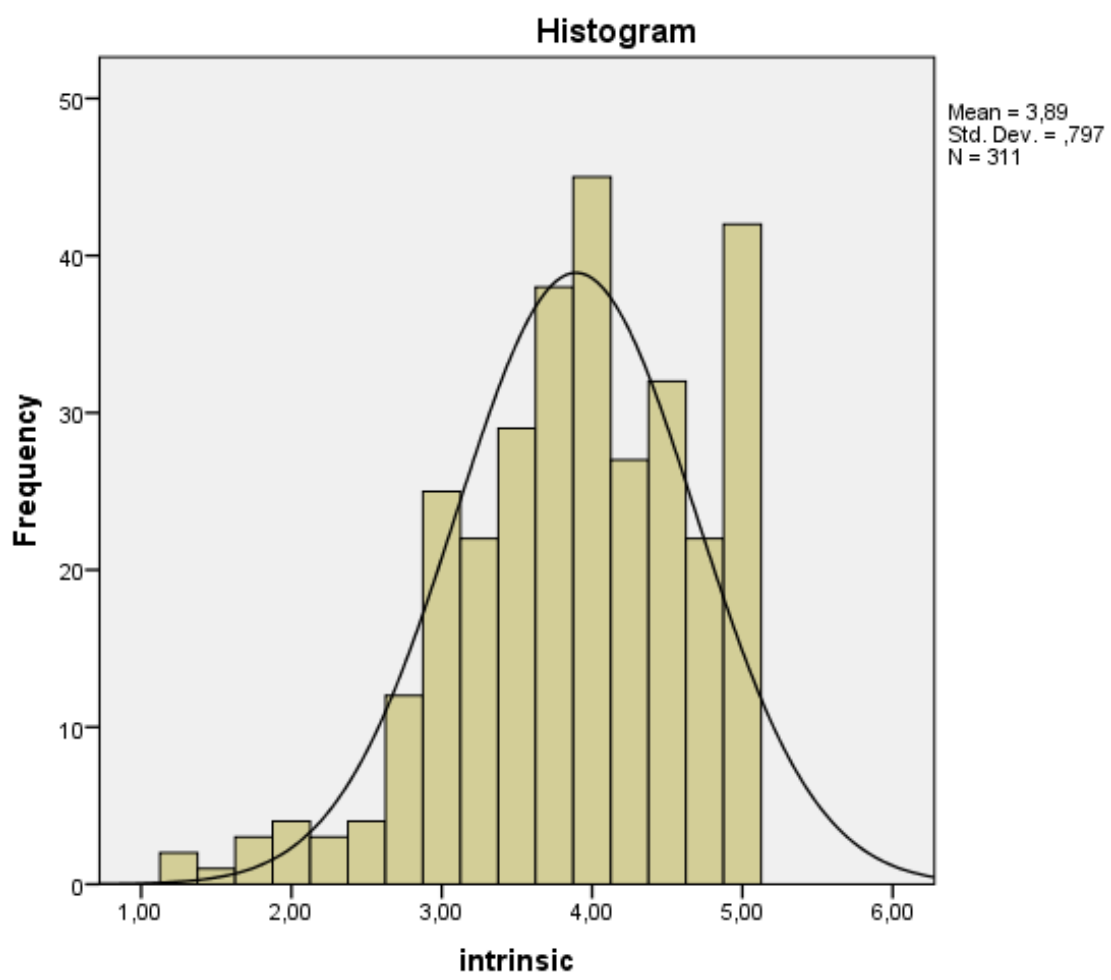

Figure 3: Frequency of intrinsic goal oriantation

Comparing by gender, there is no statistically significant difference between boys and girls $(\mathrm{t}=1.86, \Delta$ mean $=0.17, \mathrm{p}>0.05)$. Research Anderman \& Anderman (1999) shows higher intrinsic orientation in girls, while Rusilo \& Arias (2004) shows same results at this research without statistically significant difference between boys and girls. Also, there is no statistically significant difference according to the age of the participants $(\mathrm{t}=0.98, \Delta$ mean $=$ $0.09, \mathrm{p}>0.05)$ nor according to the living environment $(\mathrm{t}=1.32, \Delta$ mean $=0.12, \mathrm{p}>0.05)$. Students with higher intrinsic motivation have also much higher self-efficacy and are better in learning and acquisition of new behaviours (Lange \& Adler, 1997).

\subsubsection{Extrinsic Goal Orientation}

Descriptive results of extrinsic motivation: mean $=4.22$, median $=4.25, \mathrm{SD}=0.71$, kurt. $=$ $0.32, \min =2, \max =5$ (Figure 4). Compared with the results of Duncan et. al. (2015) which

\footnotetext{
${ }^{2}$ Original value is 5.03 at scale 1 to 7 , equivalent in scale $1-5$ is 3.59
} 
were mean $=3.59^{3}$ the results of the conducted questionnaire show significantly higher values of extrinsic motivation.

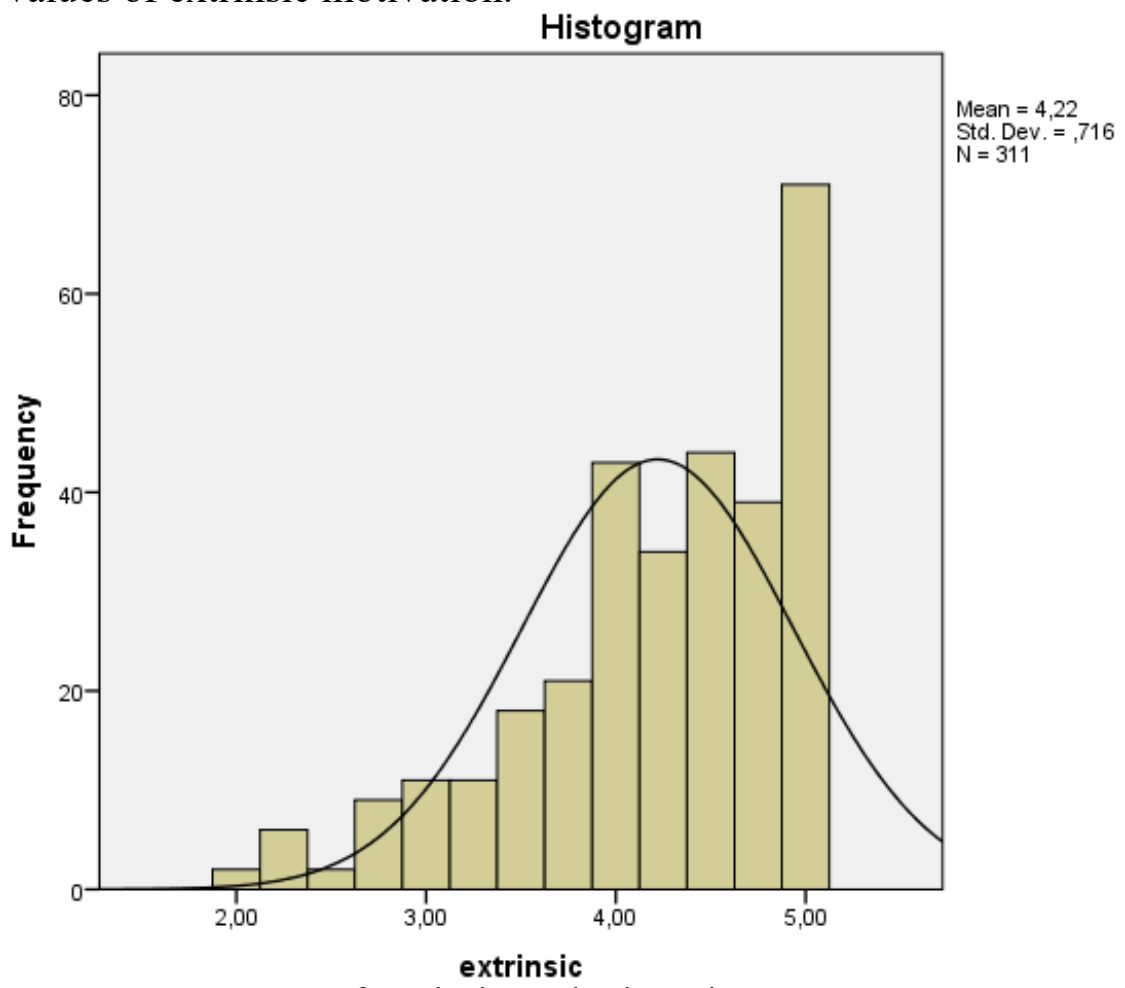

Figure 4: Frequency of extrinsic goal oriantation

As many as $22.8 \%$ of respondents had shown a maximum level (mean $=5$ ) of extrinsic motivation. Looking at gender, there is no statistically significant difference between boys and girls and the results are almost equal $(\mathrm{t}=0.01, \Delta$ mean $<0.01, \mathrm{p}>0.05)$. Similar research (Anderman \& Anderman, 1999) shows more extrinsic orientation in boys, what is not the case in this research. Also, there is no statistically significant difference according to the age of the participants $(\mathrm{t}=0.89, \Delta$ mean $=0.07, \mathrm{p}>0.05)$. Interesting are the results according to the living environment where there is a statistically significant difference $(\mathrm{t}=2.81, \Delta$ mean $=$ $0.24, \mathrm{p}<0.05)$, respondents from rural areas show a higher level of extrinsic motivation.

\subsubsection{Test anxiety}

Descriptive results of test anxiety are following: mean $=2.91$, median $=2.8, \mathrm{SD}=1.02$, kurt. $=$ $0.75, \min =1, \max =5$ (Figure 5). Compared with the results of Duncan et al. (2015) which were mean $=2.59^{4}$ the results of the conducted questionnaire show significantly higher values of test anxiety. Test anxiety is often correlated with failure at school (McKeachie, 1984).

Comparing genders there is no statistically significant difference between boys and girls $(\mathrm{t}=$ $1.41, \Delta$ mean $=0.16, p>0.05$ ). Researches (Spielberger \& Vagg, 1995; Živčić-Bećirević \& Rački, 2006) shows higher test anxiety in girls, what is not case in this research. Also, there is no statistically significant difference according to the age of the participants $(\mathrm{t}=0.48, \Delta$ mean $=0.05, \mathrm{p}>0.05)$. There is no statistically significant difference towards the living environment either $(\mathrm{t}=0.83, \Delta$ mean $=0.1, \mathrm{p}>0.05)$.

\footnotetext{
${ }^{3}$ Original value is 5.03 at scale 1 to 7 , equivalent in scale $1-5$ is 3.59

${ }^{4}$ Original value is 3.63 at scale 1 to 7 , equivalent in scale $1-5$ is 2.59
} 


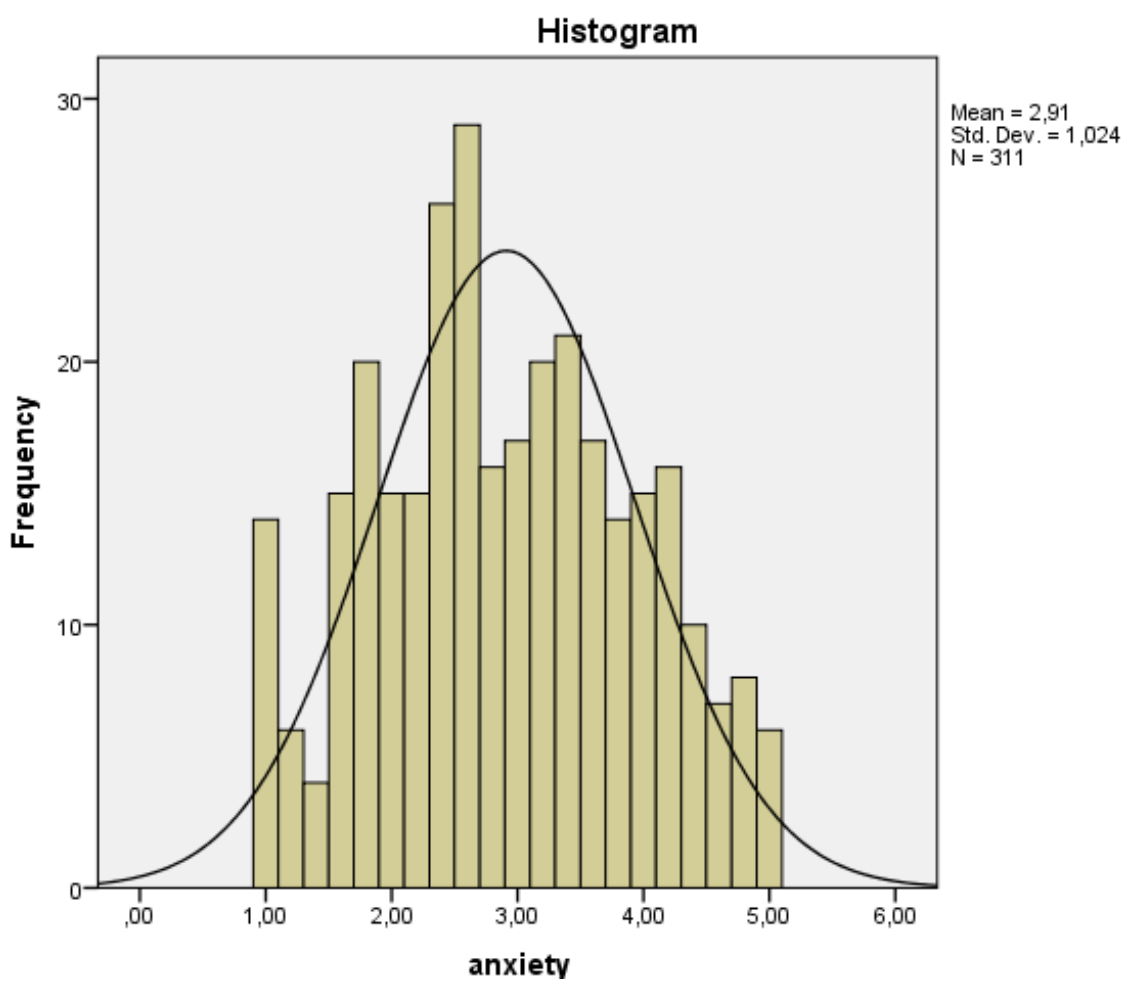

Figure 5: Frequency of test anxiety

\section{Conclusion}

Teachers need to constantly motivate their students. The most important task is to encourage the development of internal motivation. Teacher must be aware that it cannot be developed immediately, but students must be encouraged in using it. For good work organization, teacher has to know students' personality and levels of their motivation, as well as the nature of that motivation (Benček \& Marenić, 2006). Also, he has to apply the principle of realness, engage students' self - employment, didactically form the material and connect lessons with everyday life (Jakšić, 2003).

Results of this research shows that students have a high level of motivation (median $=99$ ), but also that the group is quite heterogeneous, which is shown by high levels of standard deviation of results $(\mathrm{SD}=11.15)$ and a very high range of results of as many as 56 . These results show that there are very large differences between students, which indicates irregularities in the preparation and implementation of teaching, as well as in the choice of teaching methods and strategies. Teaching must be tailored to the needs of each student and we must take care that it is equally interesting to all and maintain a high level of motivation among students.

Three motivational factors were also researched: intrinsic goal orientation, extrinsic goal orientation and anxiety. Significantly higher levels of extrinsic motivation were observed compared to intrinsic, but also higher levels of both motivations compared to the research of Duncan et al. (2015). Very interesting result is that $22.8 \%$ of respondents had shown a maximum level (mean $=5$ ) of extrinsic motivation. Statistically significant gender differences and differences according to the age of the participants were not observed in any of the three factors. Results according to the living environment shows a statistically significant difference $(\mathrm{t}=2.81, \Delta$ mean $=0.24, \mathrm{p}<0.05)$, respondents from rural areas show a higher level of extrinsic motivation and no statistically significant differences in other two factors. Rural areas students are more motivated by external factors, and teacher should take that in consideration while preparing and teaching. 


\section{References}

Altun, F. and Yazici, H. (2014). Perfectionism, School Motivation, Learning Styles and Academic Achievement of Gifted and Non - Gifted Students, Croatian Journal of Education, vol. 16, no. 4, pp. 1031-1054.

Amrai, K., Motlagh, S. E., Zalani, H. A. and Parhon, H. (2011). The relationship between academic motivation and academic achievement students. 3rd World Conference on Educational Sciences,vol. 15, pp. 399-402.

Anderman, L. and Anderman, E. (1999). Social predictors of changes in students' achievement goal orientations. Contemporary Educational Psychology, vol. 25, pp. 21-37.

Baharudin, R. and Zulkefl N. S. (2009). Relationships with Father and Mother, SelfEsteemand Academic Achievement amongst College Students. American Journal of Scientific Research, vol. 6, pp. 86-94.

Benček, A. and Marenić, M. (2006). Motivation of primary school pupils in mathematics classes, Metodički obzori, vol. 1, no. 1, pp. 104-117.

Bogdan, A. and Babačić, D. (2015). Intrinzična i ekstrinzična motivacija za sport i vježbanje u funkciji dobi, Zbornik radova Međimurskog veleučilišta u Čakovcu, Čakovec, Croatia, pp. 21-34.

Borić, E. And Škugor, A. (2014). Achieving Students' Competencies Through Research - Based Outdoor Science Teaching, Croatian Journal of Education, vol. 16, no. 1, pp. 149-64.

Borić, E. (2017). Teachers' job satisfaction, work motivation, and encouragement of competences among pupils, Metodički ogledi, 24(2), pp. 23-38.

Broussard, S. C. and Garrison, M. E. (2004). The Relationship Between Classroom Motivation and Academic Achievement in Elementary-School-Aged Children. Family and Consumer Sciences Research Journal, vol. 33, no. 2, pp. 106-120.

Dubow, E. F., Tisak, J., Causey, D., Hryshko, A. and Reid, G. (1991). A two-year longitudinal study of stressful life events, social support, and social problem-solving skills: Contributions to children's behavioral and academic adjustment. Child Development, vol. 62, pp. 583-599.

Duncan, T., Pintrich,P., Smith, D. and Mckeachie, W. (2015). Motivated Strategies for Learning Questionnaire (MSLQ) Manual. National Center for Research to Improve Postsecondary Teaching and Learning. University of Michigan.

Halusek, V. and Špoljarić, M (2014). Usporedba planiranja i pripremanja za nastavni rad na različitim nivoima školovanja, Praktični menadžment, vol. 5, no. 1, pp. 135-140.

Hammerl, B., Pucher, L., Mense, A., Wahl, H. and Schmöllebeck, F. (2009). Intrinsic Motivation and Education for Sustainability, Intrinsic Motivation - An Essential Key to Success, Sustainability, The Icfai University Press.

Jakšić, J. (2003). Motivacija. Psihopedagoški pristup. Kateheza, vol. 25, no.1, pp. 5-16.

Juretić, J. (2008). Social and Test Anxiety and Self - Efficacy Perception as Predictors of Exam Success, Psihologijske teme, vol. 17, no.1, pp. 15 - 36.

Lange, G. and Adler, F. (1997). Motivation and achievement in elementary children. The biennial meeting of th eSociety for Research in Child Development. Washington, D. C. 
McKeachie, W. (1984). Does anxiety disrupt information processing or does poor information processing lead to anxiety? International Review of Applied Psychology, vol. 33, pp. 187-203.

Matijević, M. (2005). Evaluation in Education, Pedagogijska istraživanja, vol. 2, no. 2, pp. 279-298.

Pintrich, P. R., Smith, D. A. F., García, T. and McKeachie, W. J. (1991). A manual for the use of the motivated strategies questionnaire (MSLQ). Ann Arbor, National Center for Research to Improve Postsecondary Teaching and Learning, University of Michigan.

Rusillo, M. T. and Arias, P. F. (2004). Gender differences in academic motivation of secondary school students. Electrnic Journal of Research in Educational Psychology, vol. 2, no.1, pp. 97-112.

Sakač, M., Marić, M. and Lipovac, V. (2017). School Achievement and Anxiety among Students Who Attend Extendend and After - School Day Care, Croatian Journal of Education, vol. 19, no. 4, pp. 1297-1324.

Spielberger, C. and Vagg, P. (1995). Test Anxiety, Theory, Assessment, and Treatment, Taylor \& Francis, Washington.

Stellar, J. R. and Stellar E. (1985). A Brief History of Motivation and Reward Concepts, The Neurobiology of Motivation and Reward. Springer, New York, NY.

Tomljenović, Ž. And Nikčević - Milković, A. (2005). Self - respect, test anxiety and school achievement of elementary school pupils, Contemporary psychology, vol. 8., no. 1, pp. $51-62$.

Vallerand, R. J. and O'Connor, B. P. (1989). Motivation in the elderly: A theoretical framework and some promising findings, Canadian Psychology, vol. 30, no. 3, pp. 538550 .

Vujčić, V. (2013). Opća pedagogija, novi pristup znanosti u odgoju, Hrvatski pedagoško književni zbor, Zagreb.

Wentzel, K. R. (1998). Social relationships and motivation in middle school: The role of parents, teachers, and peers. Journal of educational psychology, vol. 90, no. 2, pp. 202-209.

Zhang, G., Zeller, N., Griffith, R., Metcalf, D., Williams, J., Shea, C. and Misulis, K. (2011). Using the Context, Input, Process, and Product Evaluation Model (CIPP) as a Comprehensive Framework to Guide the Planning, Implementations, and Assessment of Service-learning Programs, Journal of Higher Education Outreach and Engagement, vol. 15 , no. 4, pp. 57-84.

Živčić-Bećirević, I. and Rački, Ž. (2006). Uloga automatskih misli, navika učenja i ispitne anksioznosti u objašnjenju školskog uspjeha i zadovoljstva učenika, Društvena istraživanja, vol. 15, no. 6 (86), pp. 987-1004. 